\title{
First Assessment of Nocturnal Lepidopteran Communities in the Forest Savannah Mosaic of the Plateaux Batéké, Southeastern Gabon
}

\author{
Hugues Bikang Bi Ateme, Stephan Ntie, Thibaud Decaëns, and Rodolphe Rougerie
}

\section{ABSTRACT}

Lepidopterans are an important component of central African biodiversity. Indeed, they play an important role as plant pollinators, food source, bio-indicators, and even pests for local crops. However, almost nothing is known about these moths in central Africa, while they are being increasingly threatened by significant landscape changes due mainly to infrastructure constructions and climate change. So, the mosaic of forests and savannah in the Plateaux Batéké (southeastern Gabon) constitutes a unique opportunity to study how Lepidopteran communities might evolve along an ecological gradient with upcoming changes in forest cover in the region. A total of 2824 specimens, representing 14 distinct families or subfamilies, were sampled using light-trapping and sorted into morphospecies, while a subset of 95 samples was further investigated using both morphological and molecular methods. Community comparison of nocturnal Lepidopteran showed that there was a significant difference in terms of abundance only between sampling sessions. Indeed, this could be due to food availability between sampling sessions. In May and June in Gabon, most plants have flowers and fruits and moth families such as Geometridae and Sphingidae emerge at that time. The most represented family in our sampled specimens was the Geometridae, which prefers habitats with permanent river courses as is the case in our sampling area. However, a more comprehensive study using various trapping methods, during several seasonal cycles and with more replicates in each habitat type is needed for a better understanding of the community structure and ecological traits that characterize nocturnal Lepidopteran in the Plateaux Batéké of Gabon.

Keywords: Gabon, Lepidoptera, molecular identification, morphological identification, Plateaux Batéké.
Published Online: December 12, 2021

ISSN: $2684-5199$

DOI : 10.24018/ejbio.2021.2.6.298

\section{H. Bikang Bi Ateme}

Cellule Scientifique, Agence Nationale des Parcs Nationaux (ANPN), BP 20379, Libreville, Gabon.

(email: huguesbikang ${ }^{@}$ gmail.com)

S. Ntie*

Laboratoire de Biologie Moléculaire et Cellulaire (LABMC), Département de Biologie, Université des Sciences et Techniques de Masuku, Franceville, Gabon.

(email: stephanntie@yahoo.fr)

T. Decaëns

Centre d'Ecologie Fonctionnelle et Evolutive, Université de Montpellier, France.

(email: thibaud.decaens@cefe.cnrs.fr)

R. Rougerie

Institut de Systématique, Évolution, Biodiversité (ISYEB), Muséum National d'Histoire Naturelle, CNRS, Sorbonne Université, EPHE,Université des Antilles, Paris, France.

(email: rodolphe.rougerie@mnhn.fr)

*Corresponding Author

\section{INTRODUCTION}

Representing more than $80 \%$ of all animals, insects are found in all habitat types where they play important roles in ecosystem functioning. For instance, insects of the easily identifiable Lepidoptera order are plant pollinators (Aker \& Udovic, 1981; Bopp \& Gottsberger, 2004; Hendrix et al., 1987), food source for other organisms (Dennis et al., 2009; Koch et al., 2005), and bio-indicators (Beccaloni \& Gaston, 1995; Erhardt, 1985; New, 1997; Valtonen et al., 2006). Among Lepidopterans, Saturniidae, Geometridae and Sphingidae are well represented in the African tropics, with new species regularly described (Brattstroem et al., 2015; Brattstroem et al., 2016; Larsen \& Rawlins, 2014; Libert, 2014; Maicher et al., 2016). There, these taxa also include several pest species for plants such as Dacryodes edulis (Poligui et al., 2015) and serve as food source for local people (Latham, 2003; Malaise \& Lognay, 2003; Michel, 1928; Nsevolo et al., 2016). However, very little is known about them in central Africa (Pierre-Baltus \& Pierre, 2000; Pierre, 2001), while biodiversity is increasingly threatened by undergoing significant landscape changes due to road construction (Blake et al., 2008; Laurance et al., 2006), timber logging (Brugiere, 1998; Laurance et al., 2008; Ndoye \& Tieguhong, 2004; Poulsen et al., 2009; Tutin, 2001; Walsh et al., 2004), mining (Edwards et al., 2014; Malhi et al., 2013), industrial plantations (Wich et al., 2014), oil production (Laurance et al., 2008; Malhi et al., 2013; Thibault \& Blaney, 2003), and climate change (Malhi et al., 2013; Voje et al., 2009; Willis et al., 2013; Wright, 2010). It is then becoming urgent to find out what Lepidopteran diversity is at stake in the region and how these species are coping with such drastic and rapid changes (AsefiNajafabady \& Saatchi, 2013; Lewis et al., 2013; Mayaux et al., 2013). For this purpose, the mosaic of natural habitats in the Haut-Ogooué province of southeastern Gabon constitutes a unique opportunity to study how Lepidopteran communities might evolve along an ecological gradient with upcoming changes in forest cover in the region (Nana, 1982). The purpose of this study was then to do a preliminary assessment of nocturnal Lepidopteran communities in southeastern Gabon, using both morphological and molecular identifications. 


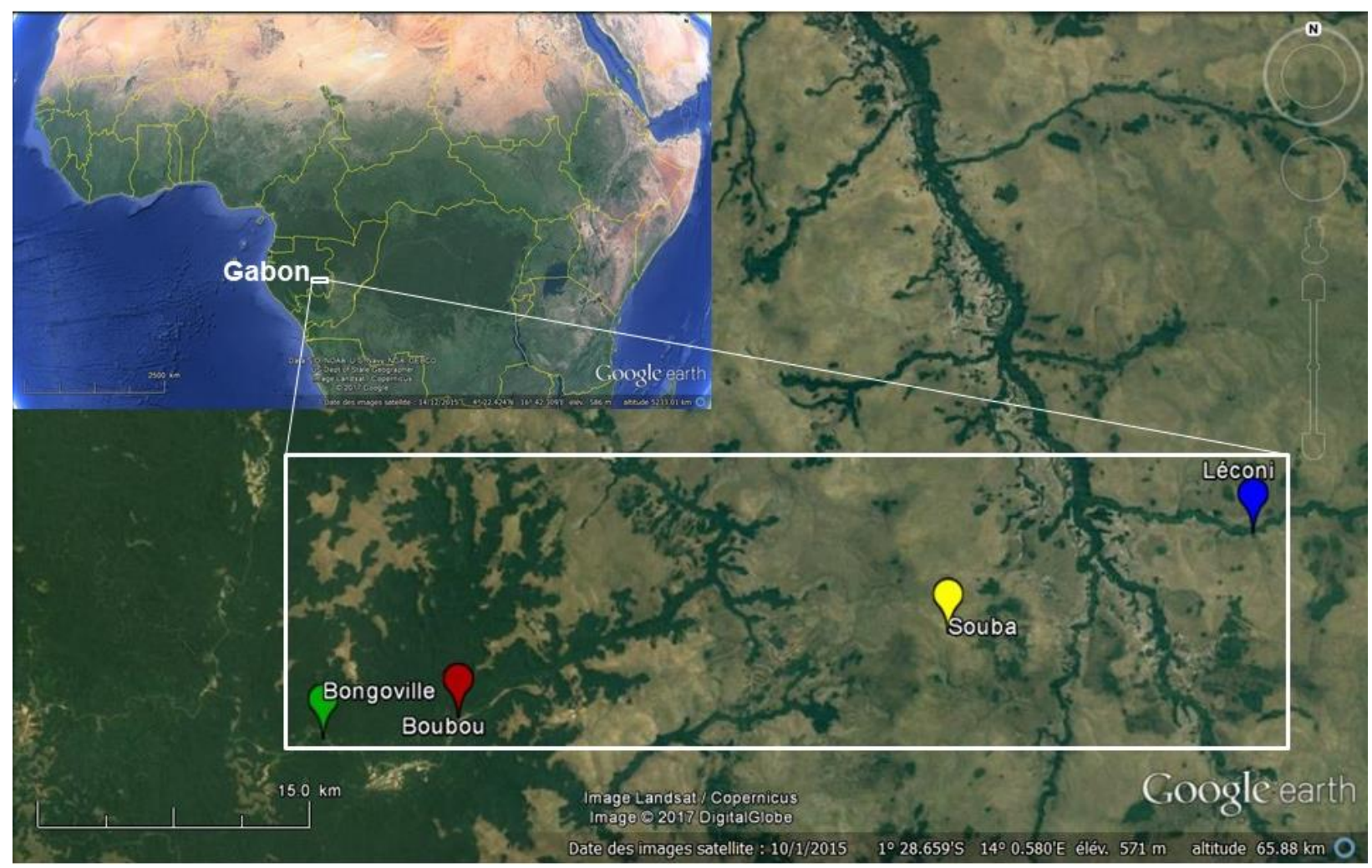

Fig. 1. Sampling locations in southeastern Gabon: Bongoville, Boubou, Souba, and Léconi.

\section{METHODS}

\section{A. Sampling Sites}

The sampling took place between May $22^{\text {nd }}$ and August $3^{\text {rd }}$, 2014, in the Djouori-Agnili department (Haut-Ogooué province), in south-eastern Gabon (Fig. 1). Four sites (named after the nearest town or village) were selected based on their vegetation types: Bongoville (S1.627 $7^{\circ}$ E13.827 ${ }^{\circ}$ ) is located in a mature forest mainly composed of large trees; Boubou $\left(\mathrm{S} 1.617^{\circ} ; \mathrm{E} 13.894^{\circ}\right)$ is located at a forest edge and is made up of grasses and large trees; Souba $\left(\mathrm{S} 1.575^{\circ}\right.$; E14.137 $)$ is located in the savannah and is composed of herbaceous vegetation (medium-sized grasses) and shrubs; and Léconi $\left(\mathrm{S} 1.525^{\circ} ; \mathrm{E} 14.290^{\circ}\right)$ is in a forest gallery mainly composed of tall trees and lianas (Fig. 1).

\section{B. Moth Collection}

In order to reduce any possible competition with moon light, a total of 24 sampling nights took place during the black moon periods of May19-30, June 25 to July 6, and July 22 to August 3 of 2014. The protocol used to collect moths was human-operated light-trapping (Chey et al., 1997), which has the advantage over automatic light-trapping of reducing damage to sampled individuals (Axmacher \& Fiedler, 2004). At each sampling site, we used an electrical power generator (1500 Watts, KINGmax KM4500DX), a white sheet of $2 \times 2 \mathrm{~m}$, two (2) low-voltage bulbs of 40 watts each (located on either side of the sheet), and a 250-watt mercury vapor lamp (acting as a call lamp) located at a height of about $1.50 \mathrm{~m}$. Collected moths were injected with ammonia or killed in cyanide jars. Finally, moths were stored in glassine envelopes identified with a unique code.

\section{Morphological Identification}

Back in the laboratory (Biology department, Université des Sciences et Techniques de Masuku, Franceville, Gabon), collected specimens went through two identification phases. The first phase consisted of grouping them into morphospecies sorted within higher taxonomic groups on the basis of the general habitus of the moths. This sorting usually at family, subfamily or possibly genus level - was verified using images available online from BOLD taxonomy browser (Barcode of Life Datasystems http://www.boldsystems.org). A second identification phase was applied to a set of 95 specimens (70 Geometridae, 15 Lymantriinae, and 10 Saturniidae) that were compared to individuals preserved in the reference collections of the Muséum national d'Histoire naturelle (MNHN), Paris (France). These specimens were selected because of the difficulty of discriminating species accurately from a superficial examination of habitus characters only. For the Lymantriinae subfamily, this second identification phase also included genitalia dissection and examination under a binocular lens (LEICA MZ75, KL 1500).

\section{Molecular Identification}

DNA extraction was carried out on the 95 selected specimens at the MNHN Molecular Systematic Service laboratory following the NucleoSpin96 kit (MACHEREYNAGEL) protocol. More specifically, a single leg was placed in each well of a 96-well plate (one well left empty as a negative control). Each well received $180 \mu \mathrm{l}$ of the extraction Buffer T1 and $25 \mu \mathrm{l}$ of Proteinase $\mathrm{K}$ at $0.02 \mathrm{mg} / \mu \mathrm{l}$. The plate was then incubated at $56{ }^{\circ} \mathrm{C}$ overnight. Further DNA extraction steps were completed automatically using an Eppendorf epMotion 5075.

Then, a fragment of 658 base pairs of the 5 'end region of the mitochondrial cytochrome oxidase I (COI) gene was 
amplified by Polymerase Chain Reaction (PCR). The amplification mix was prepared in a $5 \mathrm{ml}$ Eppendorf tube containing $1650 \mu \mathrm{l}$ of distilled water, $200 \mu \mathrm{l}$ of Buffer 2 $(10 \mathrm{mM}), 80 \mu \mathrm{l}$ of dNTP $(6.6 \mathrm{mM})$, and $32 \mu \mathrm{l}$ of each primer (LEP-F1, 5'-ATTCAACCAATCATAAAGATAT-3'; LEPR1, 5'-TAAACTTCTGGATGTCCAAAAA-3') (Hebert et al., 2004). After homogenization, $1.5 \mu \mathrm{l}$ of DNA from each sample was added to each of the 95 wells containing $20 \mu \mathrm{l}$ of the amplification mix. PCR took place in a thermocycler (Bio-RAD, C9000-Touch, CFX96 Real TimeSystem) with the following cycles: (1) hot start for $1 \mathrm{~min}$ at $94{ }^{\circ} \mathrm{C}$; (2) denaturation for 40 seconds at $94{ }^{\circ} \mathrm{C} ;$ (3) hybridization for 40 seconds at $45{ }^{\circ} \mathrm{C}$; (4) expansion for 1 minute at $72{ }^{\circ} \mathrm{C}$; (5) 5 cycles of steps 2 to 4 ; (6) denaturation for 40 seconds at $94{ }^{\circ} \mathrm{C} ;(7)$ hybridization for 40 seconds at $51{ }^{\circ} \mathrm{C} ;(8)$ extension for 1 minute at $72{ }^{\circ} \mathrm{C}$; (9) 35 cycles of steps 7 to 8 ; (10) final extension for 10 minutes at $72^{\circ} \mathrm{C}$; and indefinite storage time at $12{ }^{\circ} \mathrm{C}$ before storage of PCR products at $-9^{\circ} \mathrm{C}$ in a freezer (SJ-14T-G2S). Visualization of PCR products was carried out on a $2 \%$ agarose gel. Migration was performed at $100 \mathrm{~V}$ for $15 \mathrm{~min}$. The result of DNA migration was photographed with a digital camera (SAMSUNG, ES90) in order to visualize the quality and the size of the DNA fragments.

After sequencing of the PCR products by EUROFINS (https://www.eurofins.fr/), we used CodonCode (CodonCode Corp., Centerville, USA) for trimming primers, contig assembly and sequence editing. The sequences were then aligned using BioEdit version V7.2.5 and uploaded, along with all specimen data and images into the project "Lepidoptera of the Plateau Bateke region, Gabon" (LPBTK) on BOLD. Analyses of genetic distances and their visualization using Neighbor-Joining ( $\mathrm{NJ}$ ) were carried out using the analytical tools implemented in BOLD (default settings, using the K2P (Kimura 2-parameter) model of evolution (Kimura, 1980).

\section{RESULTS}

\section{A. Morphological Identification}

A total of 2418 specimens of nocturnal Lepidoptera were collected in the four different sites and during the three sampling sessions (Table I). The highest number of nocturnal Lepidoptera was collected in the first session of May $(\mathrm{n}=$ 1040), while the lowest number was collected in the third session of July-August $(n=430)$.

The site with the highest number of collected nocturnal Lepidoptera was Bongoville $(n=643)$, while the site with the lowest number was Souba $(n=603)$. This resulted in a significant relationship between the number of collected nocturnal Lepidoptera specimens per sampling session and locations $(\mathrm{X} 2=66.261 ; \mathrm{P}=2.383 \mathrm{e}-12)$.

Of the 14 identified families, the Geometridae were the most abundant $(\mathrm{n}=938)$ (Table I). There was a significant relationship between the number of collected nocturnal Lepidoptera specimens per family and sampling locations (P $<1 \mathrm{e}-7)$.
TABLE I: NUMBER OF SPECIMENS PER FAMILY COLLECTED IN EACH SAMPLING SITES AND THEIR TOTALS

\begin{tabular}{cccccc}
\hline \hline Families & Bongoville & Boubou & Souba & Léconi & Total \\
\hline Aganainae & 8 & 3 & 0 & 0 & 11 \\
Arctiinae & 1 & 3 & 2 & 8 & 14 \\
Chrysopolominae & 16 & 0 & 0 & 9 & 25 \\
Crambidae & 22 & 0 & 20 & 36 & 78 \\
Eupterotidae & 5 & 0 & 0 & 0 & 5 \\
Geometridae & 267 & 254 & 134 & 283 & 938 \\
Cossidae & 0 & 0 & 0 & 3 & 3 \\
Lasiocampidae & 26 & 62 & 13 & 30 & 131 \\
Limacodidae & 0 & 9 & 0 & 1 & 10 \\
Lymantriinae & 28 & 24 & 0 & 57 & 109 \\
Noctuinae & 6 & 3 & 2 & 4 & 15 \\
Nymphalidae & 0 & 0 & 1 & 0 & 1 \\
Saturniidae & 45 & 36 & 0 & 25 & 106 \\
Sphingidae & 184 & 152 & 372 & 102 & 810 \\
Unidentified & 35 & 57 & 29 & 41 & 162 \\
Total & 643 & 603 & 573 & 599 & 2418 \\
\hline \hline
\end{tabular}

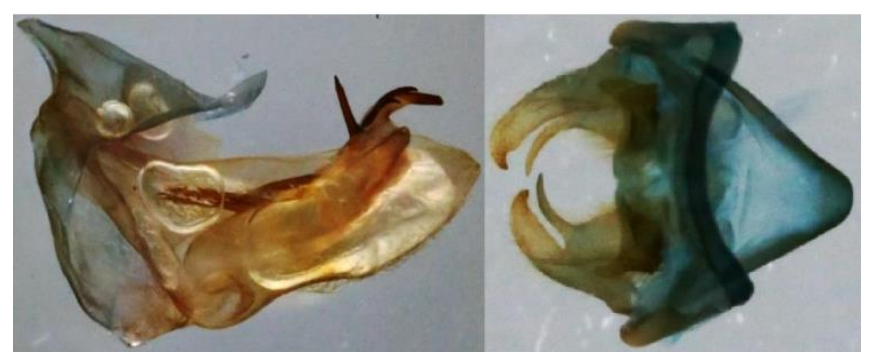

Fig. 2. Two examples of genitalia observed in selected Lymantriindae specimens.

Of the 95 specimens (70 Geometridae, 15 Lymantriidae, and 10 Saturniidae) further morphologically analyzed at the MNHN, these were grouped in 10 Geometridae, three (3) Saturniidae, and one (1) Lymantriinae morphospecies (Supplementary Table I). After careful observation, selected Saturniidae and Lymantriinae specimens were identified as belonging to genera Imbrasia and Leucoma or Euproctis, respectively.

While a superficial comparison of the moth habitus had led to the recognition of a single morphospecies among the 11 selected specimens of Lymantriinae, our comparative analysis of male genitalia morphology allowed for the discrimination of nine (9) morphospecies. This was accomplished by considering morphological variation of the general shape and size of the valves and of the uncus (Fig. 2), as well as that of the aedeagus.

\section{B. Molecular Identification}

We obtained DNA barcode sequences for 91 of the 95 specimens sampled for DNA barcoding. All are publicly available in project LEPBTK on BOLD, as well as in GenBank (see BOLD project for GenBank accession numbers). Using Barcode Index Numbers (BINs; (Ratnasingham \& Hebert, 2013) as a molecular proxy for species (as in (Hausmann et al., 2013; Ortiz et al., 2017)), our results suggest that these 91 samples (see Suppl. Fig. 1 for a visualization of these results as a $\mathrm{NJ}$ tree) may represent a total of 52 distinct species. In Lymantriinae, all nine species discriminated by their male genitalia (see above) formed unique and distinct genetic clusters (BINs). In Geometridae, the 66 DNA barcoded records comprised representatives of the 10 initially recognized morphospecies; they formed 41 distinct BINs. 


\section{DISCUSSION AND CONCLUSION}

This assessment of nocturnal Lepidopteran communities in southeastern Gabon provided a preliminary glimpse into the diversity of these moths in the Plateaux Batéké region. Estimates of species diversity carried out in the field, using a morphospecies approach, were supplemented, for a subset of the moths sampled, by a more thorough integrative approach combining morphology and DNA barcoding. This clearly revealed that preliminary sorting of specimens by morphospecies resulted in a strong underestimation of the actual species diversity, as evidenced by our subset of 14 morphospecies that turned out to represent 52 distinct BINs; a molecular proxy to species diversity. The diversity at family or subfamily level was higher in the site located within the continuous forest (namely, the Bongoville site, see Table I), probably because of a plant diversity higher than in the other sampled habitat types (Hawes et al., 2009).

Nevertheless, the four sampling locations were rather similar in terms of the total number of collected specimens and families or subfamilies. Further studies are needed however to better document similarities and differences in diversity, composition, and structure of moth communities in the region. As demonstrated here, these studies should ideally include a thorough morphological analysis or the use of DNA barcodes to assess species diversity, or a combination of both methods.

\section{APPENDIX}

TABLE I: NuMBER OF SPECIMENS PER MORPHOSPECIES, SAMPLED SITES AND THEIR TOTALS OUT OF THE 95 SPECIMENS ANALYZED BY DNA BARCODING AT THE MusÉUM NATIONAL D'HistoIRE NATURELLE

\begin{tabular}{ccccccc}
\multicolumn{7}{c}{$(\mathrm{MNHN})$} \\
\hline \hline \multirow{2}{*}{ Families } & $\begin{array}{c}\text { Morpho } \\
\text {-species }\end{array}$ & $\begin{array}{c}\text { Bongo } \\
\text {-ville }\end{array}$ & Boubou & Souba & Léconi & Total \\
\hline Geometridae & Geo1 & 6 & 0 & 2 & 0 & $\mathbf{8}$ \\
& Geo2 & 1 & 3 & 1 & 0 & $\mathbf{5}$ \\
& Geo3 & 4 & 2 & 0 & 0 & $\mathbf{6}$ \\
& Geo4 & 3 & 3 & 1 & 1 & $\mathbf{8}$ \\
& Geo5 & 3 & 4 & 0 & 0 & $\mathbf{7}$ \\
& Geo6 & 2 & 0 & 2 & 0 & $\mathbf{4}$ \\
& Geo7 & 1 & 2 & 0 & 0 & $\mathbf{3}$ \\
& Geo8 & 4 & 6 & 4 & 0 & $\mathbf{1 4}$ \\
& Geo9 & 1 & 1 & 2 & 0 & $\mathbf{4}$ \\
Lymantriidae & Geo10 & 4 & 7 & 0 & 0 & $\mathbf{1 1}$ \\
& Lym1 & 5 & 3 & 7 & 0 & $\mathbf{1 5}$ \\
& Sat1 & 1 & 0 & 3 & 0 & $\mathbf{4}$ \\
& Sat2 & 2 & 1 & 0 & 0 & $\mathbf{3}$ \\
& Sat3 & 0 & 1 & 2 & 0 & $\mathbf{3}$ \\
& & $\mathbf{3 7}$ & $\mathbf{3 3}$ & $\mathbf{2 4}$ & $\mathbf{1}$ & $\mathbf{9 5}$ \\
\hline \hline
\end{tabular}

\section{ACKNOWLEDGMENT}

Authors thank Mr MATSENGUI BOUSSAMBA Joseph, Prefect of the Ndjouori Agnili region, in providing us with all the necessary help needed while doing field work in his administrative district.

\section{CONFLICT OF INTEREST}

Authors declare that they do not have any conflict of interest. 


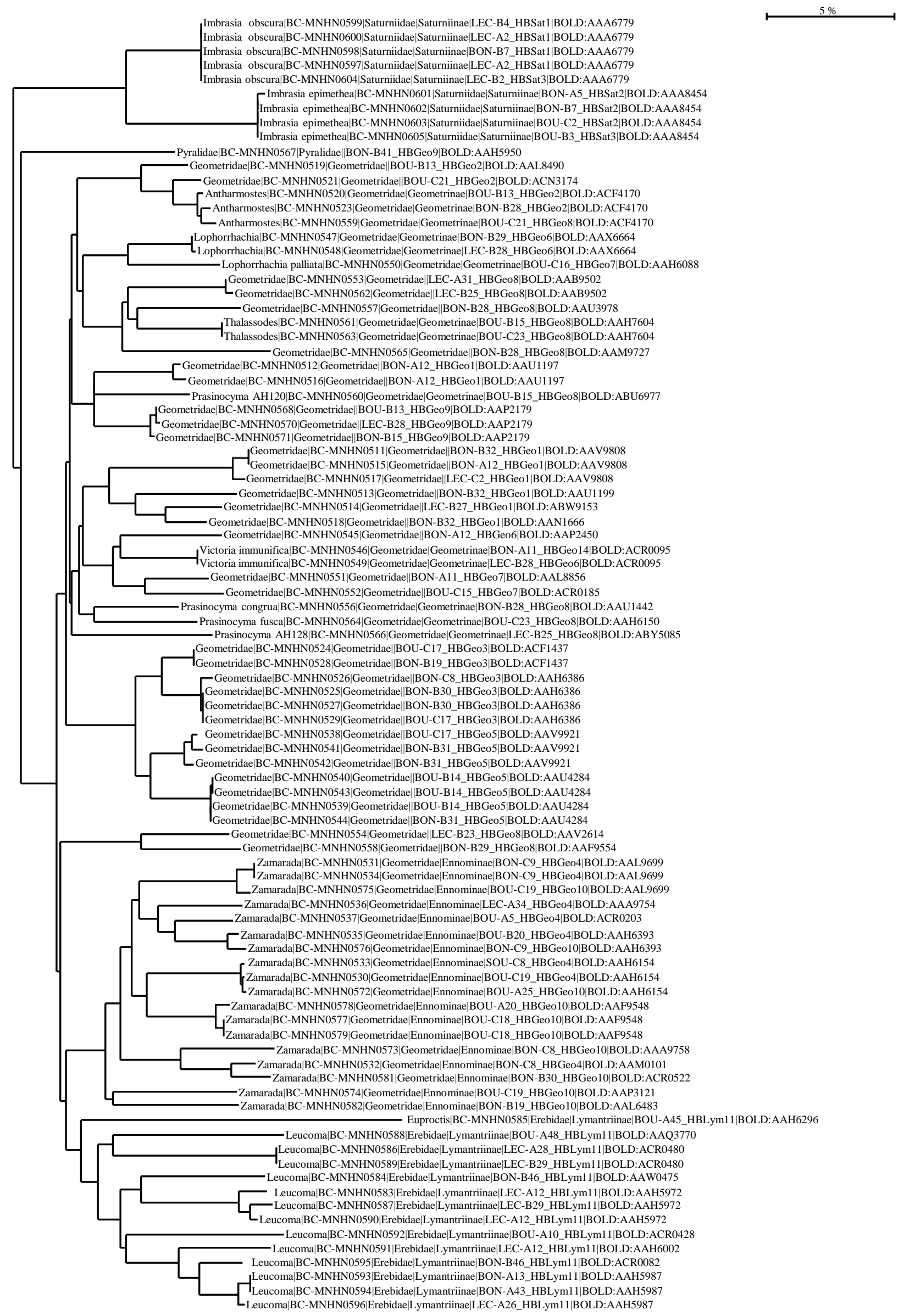

Supplementary Fig. 1. Neighbour Joining tree of 91 DNA barcode sequences generated for Lepidoptera (Geometridae, Lymantriidae and Saturniidae) of the Batéké plateau (southeastern Gabon). 


\section{REFERENCES}

Aker, C., \& Udovic, D. (1981). Oviposition and pollination behavior of the yucca moth, Tegeticula maculata (Lepidoptera: Prodoxidae), and its relation to the reproductive biology of Yucca whipplei (Agavaceae). Oecologia, 49(1), 96-101.

Asefi-Najafabady, S., \& Saatchi, S. (2013). Response of African humid tropical forests to recent rainfall anomalies. Philos Trans $R$ Soc Lond $\mathrm{B}$ Biol Sci, 368(1625), 20120306. doi:10.1098/rstb.2012.0306.

Axmacher, J. C., \& Fiedler, K. (2004). Manual versus automatic moth sampling at equal light sources-a comparison of catches from $\mathrm{Mt}$. Kilimanjaro. Journal of the Lepidopterists' Society, 58(4), 196-202.

Beccaloni, G. W., \& Gaston, K. J. (1995). Predicting the species richness of neotropical forest butterflies: Ithomiinae (Lepidoptera: Nymphalidae) as indicators. Biological Conservation, 71(1), 77-86.

Blake, S., Deem, S. L., Strindberg, S., Maisels, F., Momont, L., Isia, I.-B., Kock, M. D. (2008). Roadless Wilderness Area Determines Forest Elephant Movements in the Congo Basin. PLoS ONE, 3(10), e3546. doi:10.1371/journal.pone.0003546.

Bopp, S., \& Gottsberger, G. (2004). Importance of Silene latifolia ssp. alba and S. dioica (Caryophyllaceae) as host plants of the parasitic pollinator Hadena bicruris (Lepidoptera, Noctuidae). Oikos, 105(2), 221-228.

Brattstroem, O., Aduse-Poku, K., Collins, S. C., \& Brakefield, P. M. (2015). Revision of the Bicyclus ignobilis species-group (Lepidoptera: Nymphalidae: Satyrinae) with descriptions of two new species. Zootaxa, 4018(1), 057-079.

Brattstroem, O., Aduse-Poku, K., Collins, S. C., Di Micco De Santo, T., \& Brakefield, P. M. (2016). Revision of the Bicyclus sciathis species group (Lepidoptera: Nymphalidae) with descriptions of four new species and corrected distributional records. Systematic entomology, 41(1), 207-228.

Brugiere, D. (1998). Population size of the black colobus monkey Colobus satanas and the impact of logging in the Lope Reserve, Central Gabon. Biological Conservation, 86(1), 15-20.

Chey, V., Holloway, J., \& Speight, M. (1997). Diversity of moths in forest plantations and natural forests in Sabah. Bulletin of Entomological Research, 87(4), 371-385.

Dennis, D. S., Lavigne, R. J., \& Dennis, J. G. (2009). Lepidoptera as Prey of Robber Flies (Diptera: Asilidae) with Unpublished Records. Journal of the Entomological Research Society, 11(1).

Edwards, D. P., Sloan, S., Weng, L., Dirks, P., Sayer, J., \& Laurance, W. F. (2014). Mining and the African continent. Conservation Letters. doi:10.1111/conl.12076.

Erhardt, A. (1985). Diurnal Lepidoptera: sensitive indicators of cultivated and abandoned grassland. Journal of Applied Ecology, 849-861.

Hausmann, A., Godfray, H. C. J., Huemer, P., Mutanen, M., Rougerie, R., van Nieukerken, E. J., Hebert, P. D. (2013). Genetic patterns in European geometrid moths revealed by the Barcode Index Number (BIN) system. PLOS ONE, 8(12), e84518.

Hawes, J., da Silva Motta, C., Overal, W. L., Barlow, J., Gardner, T. A., \& Peres, C. A. (2009). Diversity and composition of Amazonian moths in primary, secondary and plantation forests. Journal of Tropical Ecology, 25(3), 281-300.

Hebert, P. D., Penton, E. H., Burns, J. M., Janzen, D. H., \& Hallwachs, W. (2004). Ten species in one: DNA barcoding reveals cryptic species in the neotropical skipper butterfly Astraptes fulgerator. Proceedings of the National Academy of Sciences, 101(41), 14812-14817.

Hendrix, W., Mueller, T., Phillips, J., \& Davis, O. (1987). Pollen as an indicator of long-distance movement of Heliothis zea (Lepidoptera: Noctuidae). Environmental entomology, 16(5), 1148-1151.

Kimura, M. (1980). A simple method for estimating evolutionary rates of base substitutions through comparative studies of nucleotide sequences. Journal of Molecular Evolution, 16(2), 111-120.

Koch, R., Venette, R., \& Hutchison, W. (2005). Influence of alternate prey on predation of monarch butterfly (Lepidoptera: Nymphalidae) larvae by the multicolored Asian lady beetle (Coleoptera: Coccinellidae). Environmental entomology, 34(2), 410-416.

Larsen, T. B., \& Rawlins, J. E. (2014). A New Species of Skipper in the Afrotropical Genus Procampta Holland (Lepidoptera: Hesperiidae: Pyrginae: Tagiadini). Annals of Carnegie Museum, 82(4), 331-335.

Latham, P. (2003). Les chenilles comestibles et leurs plantes nourricières dans la province du Bas-Congo: Armée du Salut.

Laurance, W. F., Croes, B. M., Guissouegou, N., Buij, R., Dethier, M., \& Alonso, A. (2008). Impacts of roads, hunting, and habitat alteration on nocturnal mammals in African rainforests. Conservation Biology, 22(3), 721-732.

Laurance, W. F., Croes, B. M., Tchignoumba, L., Lahm, S. A., Alonso, A., Lee, M. E., Ondzeano, C. (2006). Impacts of roads and hunting on central African rainforest mammals. Conservation Biology, 20(4), 1251-1261.

Lewis, S. L., Sonke, B., Sunderland, T., Begne, S. K., Lopez-Gonzalez, G., van der Heijden, G. M., Zemagho, L. (2013). Above-ground biomass and structure of 260 African tropical forests. Philos Trans $R$ Soc Lond B Biol Sci, 368(1625), 20120295. doi:10.1098/rstb.2012.0295.

Libert, M. (2014). Nouveaux taxons du genre Euptera Staudinger, 1891 (Lepidoptera, Nymphalidae). Bulletin de la Société entomologique de France, 119(1), 79-90.

Maicher, V., Sáfián, S., Ishmeal, K. N., Murkwe, M., Kimbeng, T. J., Janeček, Š., \& Tropek, R. (2016). Two genera and nineteen species of fruit-feeding erebid moths (Lepidoptera: Erebidae) recorded in Cameroon for the first time. Entomological News, 126(1), 64-70.

Malaise, F., \& Lognay, G. (2003). Les chenilles comestibles d'Afrique tropicale. "Insects" in oral literature and traditions, 11, 279.

Malhi, Y., Adu-Bredu, S., Asare, R. A., Lewis, S. L., \& Mayaux, P. (2013). African rainforests: past, present and future. Philosophical Transactions of the Royal Society B: Biological Sciences, 368(1625). doi:10.1098/rstb.2012.0312.

Mayaux, P., Pekel, J. F., Desclee, B., Donnay, F., Lupi, A., Achard, F. Belward, A. (2013). State and evolution of the African rainforests between 1990 and 2010. Philos Trans $R$ Soc Lond B Biol Sci, 368(1625), 20120300. doi:10.1098/rstb.2012.0300.

Michel, E. (1928). Les vers à soie sauvages du Congo belge: Brussels, Imprimerie industrielle et financière.

Nana, A. (1982). Apport de la télédétection et du SIG pour le suivi de la dynamique forêt-savane. Cas au Gabon du Parc de la Lopé de.

Ndoye, O., \& Tieguhong, J. C. (2004). Forest resources and rural livelihoods: The conflict between timber and non-timber forest products in the Congo Basin. Scandinavian Journal of Forest Research, 19, 36-44.

New, T. (1997). Are Lepidoptera an effective 'umbrella group 'for biodiversity conservation? Journal of Insect Conservation, 1(1), 5-12.

Nsevolo, P., Taofic, A., Caparros, R., Sablon, L., Haubruge, É., \& Francis, F. (2016). La biodiversité entomologique comme source d'aliments à Kinshasa (République démocratique du Congo). Annales de la Société entomologique de France (N.S.), 52(2), 57-64 doi:10.1080/00379271.2016.1186467.

Ortiz, A. S., Rubio, R. M., Guerrero, J. J., Garre, M. J., Serrano, J., Hebert, P. D., \& Hausmann, A. (2017). Close congruence between Barcode Index Numbers (bins) and species boundaries in the Erebidae (Lepidoptera: Noctuoidea) of the Iberian Peninsula. Biodiversity Data Journal (5).

Pierre-Baltus, C., \& Pierre, J. (2000). Nouveaux Zamarada de la réserve de la Lopé, Gabon (Lepidoptera, Geometridae). Bulletin de la Société entomologique de France, 105(4), 337-342.

Pierre, J. (2001). Les Sphinx du Gabon (Lepidoptera, Sphingidae). Bulletin de la Société entomologique de France, 106(3), 261-271.

Poligui, R., Mouaragadja, I., Haubruge, E., \& Francis, F. (2015). The safou red borer caterpillar Pseudonoorda edulis (Lepidoptera, Crambidae): first observations from field surveys on its biology and morphometrics in Gabon. African Entomology, 23(1), 37-42.

Poulsen, J. R., Clark, C. J., Mavah, G., \& Elkan, P. W. (2009). Bushmeat Supply and Consumption in a Tropical Logging Concession in Northern Congo. Conservation Biology, 23(6), 1597-1608.

Ratnasingham, S., \& Hebert, P. D. (2013). A DNA-based registry for all animal species: the Barcode Index Number (BIN) system. PLoS ONE, $8(7)$, e66213.

Thibault, M., \& Blaney, S. (2003). The oil industry as an underlying factor in the bushmeat crisis in Central Africa. Conservation Biology, 17(6), 1807-1813.

Tutin, C. E. G. (2001). Saving the gorillas (Gorilla g. gorilla) and chimpanzees (Pan t. troglodytes) of the Congo Basin. Reproduction Fertility and Development, 13(7-8), 469-476.

Valtonen, A., Jantunen, J., \& Saarinen, K. (2006). Flora and lepidoptera fauna adversely affected by invasive Lupinus polyphyllus along road verges. Biological Conservation, 133(3), 389-396.

Voje, K. L., Hemp, C., Flagstad, O., Saetre, G. P., \& Stenseth, N. C. (2009). Climatic change as an engine for speciation in flightless Orthoptera species inhabiting African mountains. Molecular Ecology, 18(1), 93108.

Walsh, P. D., Henschel, P., \& Abernethy, K. A. (2004). Logging speeds little red fire ant invasion of Africa. Biotropica, 36(4), 637-640. doi:10.1111/j.1744-7429.2004.tb00358.x.

Wich, S. A., Garcia-Ulloa, J., Kuhl, H. S., Humle, T., Lee, J. S., \& Koh, L. P. (2014). Will oil palm's homecoming spell doom for Africa's great apes? Curr Biol, 24(14), 1659-1663. doi:10.1016/j.cub.2014.05.077.

Willis, K. J., Bennett, K. D., Burrough, S. L., Macias-Fauria, M., \& Tovar, C. (2013). Determining the response of African biota to climate change: using the past to model the future. Philosophical Transactions of the Royal Society B-Biological Sciences, 368. doi:10.1098/rstb.2012.0491.

Wright, S. J. (2010). The future of tropical forests. In R. S. Ostfeld \& W. H. Schlesinger (Eds.), Year in Ecology and Conservation Biology 2010 (Vol. 1195, pp. 1-27). Malden: Wiley-Blackwell. 